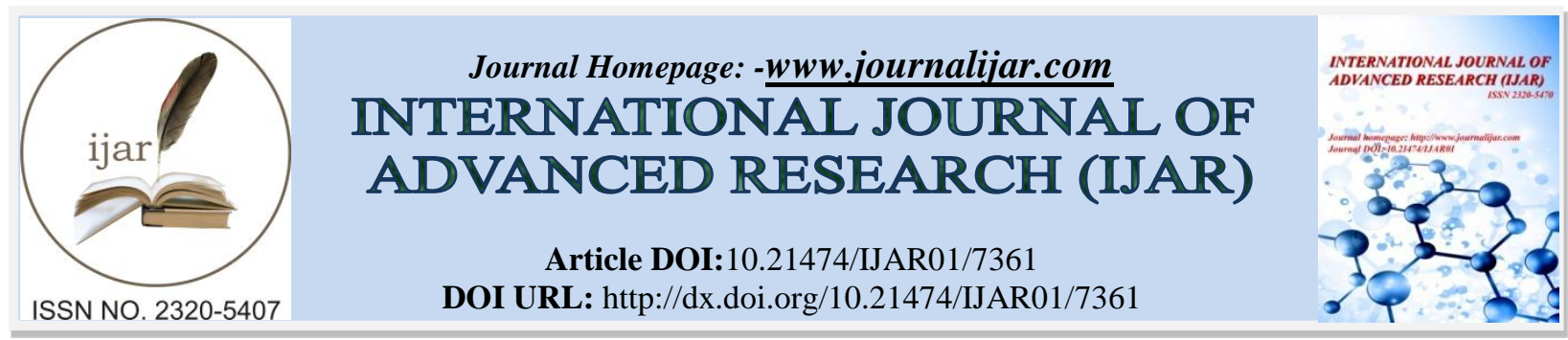

RESEARCH ARTICLE

\title{
SOCIAL ROLE OF MILITARY'S WIFE IN ORDER TO SUPPORT HUSBAND PROFESSIONALISM AS THE NATIONAL DEFENCE VANGUARD (CASE STUDY OF KARTIKA CHANDRA KIRANA NATIONAL ARMED WIVES' UNION (PERSIT) AT LIV YONARHANUDSE-8 PD V BRAWIJAYA).
}

1. Master student of brawijaya university.

2. Postgraduate lecturer of brawijaya university.

3. Postgraduate lecturer of wisnu wardhana university.

\section{Manuscript Info}

Manuscript History

Received: 07 May 2018

Final Accepted: 09 June 2018

Published: July 2018

\section{Abstract}

The purpose of this research is to: 1) Analyze characteristics of the Kartika Chandra Kirana National Armed Wives Union member at Liv Yonarhanudse-8 Pd V Brawijaya on the assessment of social support for husbands, 2) Analyze social support which is provided to increase the professionalism of husbands as soldiers, 3) Analyze the influence of social support on the professionalism of the husband as an important military role in the vanguard. The study was conducted for 3 months at Kartika Chandra Kirana National Armed Wives' Union at Liv Yonarhanudse-8 Pd V Brawijaya on November 10, 2017 to January 10, 2018.

The method that used as data collection process is survey method, where the survey method is done by the writer plunges directly to the respondent to get information related to social support as the main role of the member's wife in supporting the professionalism of the husband as the vanguard of the military. At the time of the survey, the data required are primary data and secondary data.

Determination of sample research using total sampling method but differentiate some criteria through Stratified Random Sampling where writer determine sample by selecting member of Candra Kirana member to be used as research sample. The total number of visitors in Yonarhanudse total sampling is 120 members with marriage criteria below 5 years, between 5-10 years and marriage above 10 years. Therefore, the number of respondents who used for the sample is 120 respondents. Data analysis used in observation is descriptive method to describe characteristic of soldier's wife from age, education, occupation, length of marriage, frequency of assignment of husband to abroad and outside island, then through quantitative method by calculation of SEM analysis with PLS warp method to know the influence of wife's social support for the professionalism of the husband as a soldier who plays a role in the vanguard of the military. The results of the study can be summarized as follows; 1) the characteristics of Age over 30 years old as much as $67 \%$ while 30 years less as much as $37 \%$ below 30 years. The military wives' age above 30 
years is more open-minded related to social support given and already has a good mentality to provide social support. For the military's wives last education can be mentioned as High school as much as $22 \%$, diploma $68 \%$ and bachelor as much as $10 \%$. 2) Social support provided is in the form of support through appraisal support and self-esteem support. The individual characteristics of Chandra Kirana in the Yon Arhanudse 08 neighborhood and social support have a positive influence on the professionalism of the husband as the military's vital role in the leading Guard as well.

Copy Right, IJAR, 2018,. All rights reserved.

\section{Introduction:-}

The role of women who has become a wife in the family has a lot of very big tasks. In a family, wife's role is as the main character formers in children, besides, the wife's duty is to provide good service to the family such as supporting the husband. The greatest motivator for the husband is a wife. Based on some experiences which is occurred in the social environment, that the husband's success is coming from the wife's support, lots of history reveals that behind the success husband there is a great wife. The success women become a good motivator emotionally and psychologically, a woman can have an impact on her husband, so that the husband feels motivated to do positive activities.

The wife is not only a verbal motivator (advice and criticism), but the wife is also a non-verbal motivators (preparing meals, preparing clothes, or taking care of other husbands' needs), wife as a motivator in the spirit. Some forms of social support according to Cohen \& Hoberman (in Isnawati \& Suhariadi, 2013: 3) are Appraisal Support, Tangible support, Self-esteem support, and Belonging support.

The duty of a husband who works as a soldier of the Indonesian National Army (TNI) is having the main duty of maintaining the integrity of the Unitary State of the Republic of Indonesia (NKRI). In addition to these basic tasks, TNI soldiers must be ready to be assigned abroad as a contingent of Garuda that joins UN peacekeepers. The order of duties is described in Law No. 34 of 2004 on the TNI in Article 20 paragraph 3. The article clearly states that TNI soldiers carry out the task of world peace in accordance with Indonesian foreign policy. TNI soldiers assigned as world peace forces are called Garuda contingents, Garuda contingents are TNI soldiers assigned to join peacekeeping forces in other countries, under the banner of the UN.

The professionalism position of a married soldier is to be willing to leave his family. In a family, soldier is a husband for his wife and father for his son. While on duty a lot of energy and thoughts are divided, as a husband has an obligation to keep and protect the family at all times. It can make the role of the wives they leave in relation to the humanitarian task will be more severe, because the wives of the soldiers must carry the duties of the husband during her husband in the field of duty.

The phenomenon of TNI soldier's wife who is being left by husband related to husband's duty in peacekeeping mission in Lebanon can be taken from the wife of TNI Army soldier (TNI-AD). This research especially was done in one of unity of TNI-AD reside in Serang city. According to (AD / ART PERSIT 2010), TNI-AD soldier's wife is absolutely inseparable from TNI-AD, both in performing organizational duties and in private life. Therefore, the wives of the soldiers must help the Army in succeeding their duties. From the above explanation can be concluded that a wife of soldiers of the Army must always be ready in live duty if the husband is assigned anywhere and anytime.

All wives of soldiers are required to join into the organization of Armed Wives' Union (PERSIT) Kartika Chandra Kirana. PERSIT is one of the women's organizations comprised of TNI-AD wives. The establishment of PERSIT organization is very helpful to the wives of the soldiers in forming a strong and steadfast personality. From PERSIT's organization the soldier's wives gain a lot of useful experience and knowledge both for families and the surrounding community. Wives can feel the sense of the same destiny and fellow members PERSIT as perceived by the soldiers in the field of duty (Penkostrad, 2009). The soldiers' wives get many advantages during joining the membership of PERSIT, such as science, experience, and most importantly is a new family. The soldiers' wives left 
by the task of getting activities from unity, by following the activities of the unity can slightly lighten the burden when feeling lonely because the husband is on duty. PERSIT also helps the wives of soldiers to overcome the problems they face.

The problem faced by the soldier's wife who was left duty is her role as a housewife. They should be able to resolve domestic issues, such as parenting, domestic work, it often leads to conflicts in a wife. Moreover to overcome the problem requires the support of the husband, but a soldier's wife who is left duty is required to overcome the problem itself. That situation becomes psychological for a wife with her role as a housewife. The situation often makes a wife feel physical and psychological fatigue.

The contribution between the wife's social support in order to increase the husband's professionalism of as a soldier is one of the real polemic faced by the wife of military member especially who work as warrior, because the duty is very big even not infrequently to serve far both in Indonesia or going abroad so that husbands must leave their wives and children temporarily for their responsibility as soldiers and professionalism in working in the field of state defense, even life is at stake. It makes a soldier's wife should behave and have a strong mentality in providing motivation to the husband. The motivation of the wife is a big factor that can give the husband encouragement to work more professionally although the family should be left for a while.

Based on the background described above, the role of the wife in supporting the family is very big, especially in providing social support to the husband so that the professionalism of the husband especially in the field of military as the vanguard in the work environment depends on the many or least support of the wife in contributing to the success of the husband and increase the professionalism of soldiers in Yon Arhanudse 8 PD V Brawijaya.

\section{Research Purpose:-}

Based on the background described above, the purposes of this research are: 1) Analyzing the characteristics of the Kartika Chandra Kirana National Armed Wives Union member at Liv Yonarhanudse-8 Pd V Brawijaya on the assessment of social support for husbands, 2) Analyzing social support which is provided to increase the professionalism of husbands as soldiers, 3) Analyzing the influence of social support on the professionalism of the husband as an important military role in the vanguard.

\section{Research Method:-}

\section{Location and Time of Research:-}

The research was conducted for 3 months in Persit Kartika Chandra Kirana Branch LIV Yonarhanudse-8 PD V Brawijaya on November 10, 2017 to January 10, 2018. The selection of research location is done through purposive method which means that the writer doing research in Persit Kartika Chandra Kirana LIV Yonarhanudse Branch -8 PD V Brawijaya has several criteria as research objectives to be implemented, where currently the unit of Persit Kartika Chandra Kirana Branch LIV Yonarhanudse-8 PD V Brawijaya is a Persit unit that has the improvement of ability, to obtain the reward so much support involved in environment Persit Kartika Chandra Kirana Branch LIV Yonarhanudse-8 PD V Brawijaya, where soldiers who already have family, wife role so big in supporting the success of husband.

\section{Research methods:-}

The method used as data collection process is survey method, where the writer must plunge directly to the respondent to get information related to social support as the main role of the member's wife in supporting the professionalism of the husband as the vanguard of the military. At the time of the survey, the data required are primary data and secondary data.

\section{Sampling Method:-}

The sampling method was using total sampling method but it was differentiate with some criteria through Stratified Random Sampling where writer determine sample by selecting member of Candra Kirana member to be used as research sample based on criteria desired by writer, where criteria as research sample is marriage period of the warrior, for first criterion where the respondents married with the soldiers for less than 5 years, the second criteria where the respondents married with members between 5-10 years and the criteria of the third criteria where the respondents married with members over 10 years, then the second criteria was used by the writer. 
Simple Random Sampling method where the selection of research sample is determined based on random which means of predetermined criteria means that the writer is entitled to make all members of Persit as research respondents. The determination of the number of samples is minimally done with the consideration that the representative samples can be represented from the population by therefore the sample determination formula can be written as follows: Slovin 1960 in (Sevilla, at al, 1993)

The total number of PERSITS's member in Yonarhanudse total sampling is 120 members with marriage criteria below 5 years, between 5-10 years and marriage above 10 years, therefore, the number of respondents who used the sample of 120 respondents.

\section{Data Collection Method:-}

Based on the research method used by survey method, the appropriate approach in data collection is through interview, observation and documentation.

\section{Data analysis method:-}

Based on the formulation of the problem presented in Chapter I, the data analysis used in the observation is descriptive method to describe the characteristics of wives of warriors ranging from age, education, occupation, length of marriage, the frequency of assignment of husbands abroad and outside the island, then through quantitative methods through calculation of SEM analysis with warpPLS method to determine the effect of wife's social support on the professionalism of husband as a soldier who plays role in vanguard.

\section{Research Result And Discussion:- \\ Data analysis:- \\ Validity test:-}

Validity test of the data obtained from the instrument in the form of a questionnaire was aimed to determine the suitability between the measured tool (questionnaire) and what is measured (statement in the questionnaire) so that the data used for the test results of the instrument used to test the validity of the instrument so that based on the type of its usefulness then the validity can divided into content validity, that is testing based on theoretical basis or the opinion of experts or called face validity, the validity of the criteria is the type of validity that the way of measurement by comparing the correlation value between each item with corrected score by using a method called product correlation technique moment or inter correlation method. Based on the test table discriminant validity outer model by using cross loading above, it can be explained that each indicator has the largest loading value on the variable measured. Thus, from this test it can be concluded that the discriminant validity outer model has been met. Based on the results of statistical data processing using WarpPLS then obtained the results for the validity test consisting of the feasibility of cross loading, discriminant and convergent) obtained results in the following table.

Tabel 1:-Convergent Validity (Combined Loading and Cross Loading)

\begin{tabular}{|l|l|l|l|l|l|l|l|l|l|}
\hline & $\mathrm{X} 1$ & $\mathrm{X}$ & $\mathrm{Y}$ & Type $(\mathrm{a}$ & $\mathrm{SE}$ & $\mathrm{P}$ value & VIF & WLS & ES \\
\hline $\mathrm{x} 1.1$ & 0.290 & 0.000 & 0.000 & Formati & 0.092 & 0.001 & 1.555 & 1 & 0.205 \\
\hline $\mathrm{x} 1.2$ & 0.075 & 0.000 & 0.000 & Formati & 0.098 & 0.222 & 1.138 & 1 & 0.014 \\
\hline $\mathrm{x} 1.3$ & 0.318 & 0.000 & 0.000 & Formati & 0.092 & $<0.001$ & 2.039 & 1 & 0.247 \\
\hline $\mathrm{x} 1.4$ & 0.174 & 0.000 & 0.000 & Formati & 0.095 & 0.035 & 1.764 & 1 & 0.074 \\
\hline $\mathrm{x} 1.5$ & 0.218 & 0.000 & 0.000 & Formati & 0.094 & 0.011 & 1.281 & 1 & 0.116 \\
\hline $\mathrm{x} 1.6$ & 0.187 & 0.000 & 0.000 & Formati & 0.095 & 0.026 & 1.183 & 1 & 0.085 \\
\hline $\mathrm{x} 1.7$ & 0.313 & 0.000 & 0.000 & Formati & 0.092 & $<0.001$ & 1.864 & 1 & 0.239 \\
\hline $\mathrm{x} 1.8$ & 0.090 & 0.000 & 0.000 & Formati & 0.098 & 0.180 & 1.667 & 1 & 0.019 \\
\hline $\mathrm{x} 2.1$ & 0.000 & 0.447 & 0.000 & Formati & 0.089 & $<0.001$ & 3.650 & 1 & 0.415 \\
\hline $\mathrm{x} 2.2$ & 0.000 & 0.181 & 0.000 & Formati & 0.095 & 0.030 & 1.124 & 1 & 0.068 \\
\hline $\mathrm{x} 2.3$ & 0.000 & 0.129 & 0.000 & Formati & 0.097 & 0.092 & 1.059 & 1 & 0.034 \\
\hline $\mathrm{x} 2.4$ & 0.000 & 0.213 & 0.000 & Formati & 0.094 & 0.013 & 1.194 & 1 & 0.094 \\
\hline $\mathrm{x} 2.5$ & 0.000 & -0.043 & 0.000 & Formati & 0.099 & 0.333 & 1.071 & 1 & 0.004 \\
\hline $\mathrm{x} 2.6$ & 0.000 & 0.431 & 0.000 & Formati & 0.089 & $<0.001$ & 3.337 & 1 & 0.385 \\
\hline $\mathrm{z} 1$ & 0.000 & 0.000 & 0.291 & Reflect & 0.092 & 0.001 & 1.130 & 1 & 0.165 \\
\hline $\mathrm{z} 2$ & 0.000 & 0.000 & 0.057 & Reflect & 0.098 & 0.281 & 1.042 & 1 & 0.006 \\
\hline $\mathrm{z} 3$ & 0.000 & 0.000 & 0.431 & Reflect & 0.089 & $<0.001$ & 1.792 & 1 & 0.363 \\
\hline
\end{tabular}




\begin{tabular}{|l|l|l|l|l|l|l|l|l|l|}
\hline z4 & 0.000 & 0.000 & 0.223 & Reflect & 0.094 & 0.010 & 1.063 & 1 & 0.097 \\
\hline z5 & 0.000 & 0.000 & 0.434 & Reflect & 0.089 & $<0.001$ & 1.829 & 1 & 0.368 \\
\hline
\end{tabular}

(Proceed data ,WarpPLS,April 2017)

Based on the results of validity testing, it is known that the type of validity used in the study is the validity criteria that the value p-yvalue $<0.05$ because the convergent validity required for testing an instrument in the form of questionnaires and for the second condition is the value of loading should be greater than the value of cross loading then discriminant validity is said to be fulfilled. A research can be said to be valid if the research is able to minimize the occurrence of errors and irregularities that may cause a bias in a research data so that the results are not good even not in accordance with the reference comparison, if the data is bias, it cannot be proceed in the next test step. In data processing using warpPLS in validity table obtained result that p-value was $<0,001$ and loading value $>$ cross loading, then research data is valid.

\section{Reliability Test:-}

Reliability means that the instruments used in the research should be reliable. In the reliability test there are three types of ways to test the reliability, such as retest test, alternative-forms and internal consistency. An example of a type of reliability test that uses internal consistency is through the coefficient of Cronbach alpha value, where if the alpha is greater than 0.5 it can be shown that the instrument is reliable (Malhotra, 1992).

Internal consistency test indicator outer structural model is done by calculating composite reliability in each latent variable. The indicator is said to have good internal consistency if the composite reliability value of the latent variable is larger than 0.6 (Ghozali, 2008).

In designing an instrument then the most important correlation test before entering on the analysis activity then the data must be valid and reliable in order to process can be continued on the analysis of warpPLS. In the use of warpPLS software reliability testing has 2 criteria of reliability test with the same type of consistency, among others, composite reliability coefficient and alpha Cronbach coefficient are presented in the following table.

Table 2:-Composite Reliability

\begin{tabular}{|l|l|l|}
\hline X1 & X & Y \\
\hline 0.748 & 0.668 & 0.721 \\
\hline
\end{tabular}

(Data processed, WarpPLS, April 2017)

Based on the results of reliability testing with the criteria for composite reliability, the data will be reliable if it was more than 0.6 so if the value of composite reliability is less than 0.6 then the data is not reliable so that in the process of data analysis will cause bias later. In the table reliability of the figures show more than 0.6 so it can be said reliable, so from this test can be concluded that the indicators of the constituent latent variable has a good internal consistency.

Table 3:-Reliability with Alpha Cronbach

\begin{tabular}{|l|l|l|}
\hline X1 & X & Y \\
\hline 0.634 & 0.513 & 0.539 \\
\hline
\end{tabular}

(Data processed, WarpPLS, April 2017)

Based on the results of the processing of reliability using warpPLS obtained results that the number shows more than 0.6 so that the data is said to be reliable.

Testing the Goodness of Fit Structural Model (Inner Model):-

Goodness of Fit Model in the analysis of warpPLS is an index and measure in assessing good relationship in a correlation between latent variables (inner model). In the fit and quality indices section, we present the results of the three indicators in the model of fit measurements: Average Path Coefficient (APC), Average R-Squared (ARS) and Average Variance Inflation Factor (AVIF) so that an evaluation of a model can be performed. The p-value values for APC and ARS should be less than 0.05 or that the model evaluation is significant. AVIF as a multi co-linearity indicator must be smaller than 5 so that with three criteria that have been determined then the output indicates if the goodness of fit model has been met with the value of APC and ARS respectively of 0.478 and ARS 0.784 and 
significant and AVIF value of 1.622 has been fulfilled criteria. Testing the Goodness of Fit model is important because the goal is to determine the best model of the existing model (competing model).

Comparison of models is considered very important if the goal as competing models with ARS, AVIF and APC sequence because APC can occur is likely to be lower if tredapat differences in path coefficient sign. The use of the PLS regression method was chosen in this study because there was a non-linear relationship of curve $S$ to know the Social Role of Warrior's Wife in Order to Support the Professionalism of Husband as the Front Guard of State Defence Case Study of Persit Kartika Chandra Kirana Branch LIV Yonarhanudse-8 PD V Brawijaya.

Tabel 4:-Output Path Coefficient

\begin{tabular}{|l|l|l|l|}
\hline & $\mathrm{X} 1$ & $\mathrm{X}$ & $\mathrm{Y}$ \\
\hline $\mathrm{X} 1$ & & & \\
\hline $\mathrm{X}$ & & & \\
\hline $\mathrm{Y}$ & 0.238 & 0.718 & \\
\hline
\end{tabular}

(Data Proceed, WarpPLS, April 2017)

Tabel 5:-Output P-Values

\begin{tabular}{|l|l|l|l|}
\hline & $\mathrm{X} 1$ & $\mathrm{X}$ & $\mathrm{Y}$ \\
\hline $\mathrm{X} 1$ & & & \\
\hline $\mathrm{X}$ & & & \\
\hline $\mathrm{Y}$ & 0.006 & $<0.001$ & \\
\hline
\end{tabular}

(Data Proceed, WarpPLS, April 2017)

Based on the output table of coefficient and p-values output, it is obtained that PERSIT member and wife's social support have positive and significant influence to professionalism of soldier as the vanguard of national defence, characteristic of members of representatives represented by long marriage and reason of married wife with TNI soldier -AD while social support is represented by wife's support appraisal and wife's support of wife. Output WarpPLS is standardized data so that it can be interpreted the greater the coefficient of the path, the stronger the effect.

\section{Latent Variable Coefficient Output:-}

In the discussion of goodness of fit in a new model made by the author as one of the explanatory research activities then calculating the magnitude of the coefficient of determination felt very important, because R-squared goal is to show the percentage of response variables that can be explained by predictor variables, the higher the value coefficient of determination obtained (close to 1 or $100 \%$ ) then the model will be better value and if the model is lower (away from 1 or 100\%) then the calculation on the model made can be said to be biased. The result of Rsquared calculation is described in the following table.

Tabel 6:-R-Squared

\begin{tabular}{|l|l|l|}
\hline X1 & X & Y \\
\hline & & 0.784 \\
\hline
\end{tabular}

(Data Proceed, WarpPLS, April 2017)

Based on the output presented in the R-squared table it is found that the R-squared or commonly referred to as the coefficient of determination for the characteristics of soldier's wife in Yon Arhanudse 08 and social support has a positive influence on Army proportional of $78.4 \%$ and the rest by other variables outside of research and error. The criterion of measurement in the next goodness of fit is to observe the Average Varian Extracted (AVE) value of the objective is to measure the evaluation on convergent validity which has a condition that the value should be>0.5. Output AVE is described in the following table.

Table 7:-Outup AVE

\begin{tabular}{|l|l|l|}
\hline X1 & X & Y \\
\hline 0.504 & 0.545 & 0.591 \\
\hline
\end{tabular}

(Data processed, WarpPLS, April 2017) 
Based on the Average Output Average Extracted table it is known that overall response variables and predictor variables observed have AVE value> 0.5 which means that individual characteristic variables of members of PERSIT Chandra Kirana Yon Arhanudse 08 and social support have an influence on Husband Professionalism as the national Defence Vanguard are eligible for convergent validity.

The next Goodness of Fit feasibility test is a VIF Full co-linearity which is a full-scale culmination measurement that includes multi co-linearity vertically and laterally. The lateral clinic is the cultivation between the latent variable of the predictor and the criterion and can be used to test the common method of bias, the criterion value used in the VIF standard is $<3.3$ and the following is the warpPLS output on the VIF measurement.

Table 8:-Full Collinerity VIF

\begin{tabular}{|l|l|l|}
\hline $\mathrm{X} 1$ & $\mathrm{X}$ & $\mathrm{Y}$ \\
\hline 1.853 & 3.930 & 4.387 \\
\hline
\end{tabular}

(Data processed, WarpPLS, April 2017)

Based on the output table of Full co-linearity test results obtained that for all variables observed have numbers that are in accordance with the VIF criteria that is $<3.3$ then it can be assumed no multi co-linearity (between independent variables should be free).

Output Correlations among Latent Variables:-

Output Correlations among Latent Variables is the correlation coefficient between variables accompanied by p-value results. These results are needed as an evaluation of the validity of the study instrument's discriminatory. The criterion used is the square root of the AVE value that is the diagonal value and bracketed must be higher than the correlation between the latent variables in the same column. Here is a table Output Correlations among Latent Variables.

Table 9:-Output Correlations among Latent Variables

\begin{tabular}{|l|l|l|l|}
\hline & $\mathrm{X} 1$ & $\mathrm{X}$ & $\mathrm{Y}$ \\
\hline $\mathrm{X} 1$ & 0.552 & 0.624 & 0.673 \\
\hline $\mathrm{X}$ & 0.624 & 0.588 & 0.861 \\
\hline & 0.673 & 0.861 & 0.625 \\
\hline
\end{tabular}

(Data processed, WarpPLS, April 2017)

Based on the Output Correlations among Latent Variables table, the validity for the characteristic components of soldier wives in Yon Arhanudse 08 and social support had a positive influence on TNI-AD soldiers' proportional fulfilled because the AVE root value of 0.861 was greater than 0.673 as in the case of Social Support wife of the soldier as a member of PERSIT whose position is the response variable and the predictor is taken with the root value of the highest AVE.

Table 10:-P Values for Correlations

\begin{tabular}{|l|l|l|l|}
\hline & $\mathrm{X} 1$ & $\mathrm{X}$ & $\mathrm{Y}$ \\
\hline $\mathrm{X} 1$ & 1.000 & $<0.001$ & $<0.001$ \\
\hline $\mathrm{X}$ & $<0.001$ & 1.000 & $<0.001$ \\
\hline $\mathrm{Y}$ & $<0.001$ & $<0.001$ & 1.000 \\
\hline
\end{tabular}

(Data processed, WarpPLS, April 2017)

Based on the output table $\mathrm{p}$ values observed through warpPLS obtained the result that the $\mathrm{p}$-value that shows the value $<0.001$ means the correlation is very strong.

\section{Block Variance Inflation Factors Output:-}

Output Block Variance Inflation Factors presents the results of vertical co-linearity testing that is the predominance of predictor variables. VIF values are presented for each of the criterion variables that indicate the level of cultivation between the independent variables. The criterion is the same as the full co-linearity test, which must be $<3.3$ so it can be stated that there is no vertical co-linearity problem in the study. VIF values are presented in the following table. 
Table 11:-VIF

\begin{tabular}{|l|l|l|}
\hline $\mathrm{X} 1$ & $\mathrm{X}$ & $\mathrm{Y}$ \\
\hline $\mathrm{X} 1$ & & \\
\hline $\mathrm{X}$ & & \\
\hline $\mathrm{Y}$ & 1.622 & 1.622 \\
\hline
\end{tabular}

(Data processed, WarpPLS, April 2017)

Based on the results of data analysis conducted using warpPLS program known that the VIF value in accordance with the criteria of value $<3.3$ so that in this study there is no problem of co-linearity.

Total Effect and P-Value Total Effect:-

Total Effect and P-Value Total Effect is one of the requirements used in the analysis to determine the effect of each manifest on the predictor variable to the response variable. The influence in a variable is observed from the $p$-value value, if $\mathrm{p}<0.001$ then the predictor variable has a significant influence on the response variable, if $p>0,05$ then it means that the predictor variable has no significant effect on the response variable. Based on the results of data analysis using PLS, then obtained the value of Total Effect and P-Value Total Effect as follows.

Table 12:-Total Effect

\begin{tabular}{|l|l|l|l|}
\hline & $\mathrm{X} 1$ & $\mathrm{X}$ & $\mathrm{Y}$ \\
\hline $\mathrm{X} 1$ & & & \\
\hline $\mathrm{X}$ & & & \\
\hline $\mathrm{Y}$ & 0.238 & 0.718 & \\
\hline
\end{tabular}

Source: (Data processed, Warp PLS, April 2017)

Based on the warpPLS output on the total effect it is known that some variables marked bold are predictor variables that have significant influence on the response variable, each latent variable has one manifest variable that has strong influence so that it can represent the latent variable to influence the response variable. The strongest weight in a latent variable can be seen in the attachment for the weight indicator. The individual characteristics of soldier wives as members of the squad represented by long marriage and the reason of marriage with members of the Army have a positive impact on the professionalism of TNI-AD soldiers as the vanguard of national defence, as well as social support in the form of emotional and belonging support from wives to improve the professionalism of the husband as a member.

Structural Model of Persit Candra Kirana Branch LIV Yonarhanudse-8 PD V Individual Characteristic member influence and wife's social support to Professionalism Husband as National Defence Vanguard:-

The structural model using Partial Least Square is a model of a construct model that aims as the development of a theory owned by the author in developing an existing model, so that PLS-SEM aims to test the predictive relationship between constructs by seeing whether there is a relationship or influence between constructs by looking whether there is a connection or influence between them. The consequence of the use of PLS-SEM is that testing can be done without a strong theoretical basis, ignoring some (non-parametric) assumptions and predictive model prediction parameters seen from the coefficient of determination (R-Square). Therefore, PLS-SEM is very appropriate to use in research that aims to develop the theory. In the SEM method there are several variables called as predictor, response and mediation variables, where the mediation variable is the connecting variable between the predictor variable and the response variable. The mediation variable may change to the response variable if it is influenced by the predictor variable and capable of being a predictor variable if it has an effect on the response variable.

Mediator variables are also called intervening variables or intermediate variables which theoretically influence observed phenomena (endogenous variables), whose effects must be inference through the effect of the relationship between exogenous variables and their phenomenon. If the exogenous variables no longer have an effect on the endogenous variables after controlling for the mediator variables, a perfect or complete mediation occurs. If the influence of exogenous variables on endogenous variables decreases, but is still different from 0 , after controlling the mediator variable, there is partial mediation (Jogiyanto and Abdillah, 2009). 
The reason the authors use warpPLS as a tool in statistical data processing that the approach taken to determine the effect of variables with complexity and many constructs and indicators in the form of recursive that requires a variance approach, so that the weight of each grain can be seen so that the writer knows the value of weighting that is able to represent latent variables as a predictor to influence the response variable. Here is a picture of structural models in related research Structural Model Characteristics Individual wife of soldiers of the Army and the role of social wives as members of the persit against the professionalism of soldiers as the National Defence Vanguard in Yon Arhanudse 08.

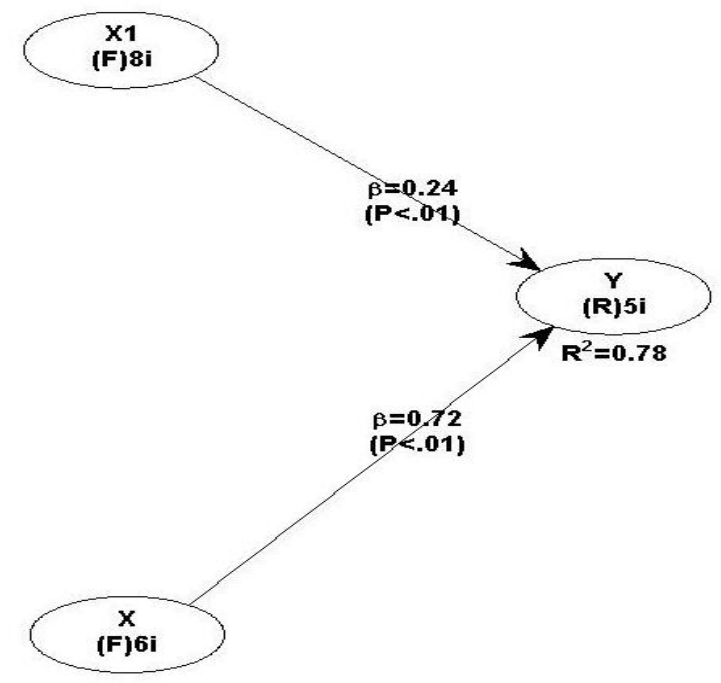

Figure 1:-Interpretation Line

Based on the result of data analysis using WarpPLS 5 it is known that the individual characteristics of soldier's wife as a member of PERSIT represented by long married and the reason of decision to become the wife of soldier of TNI-AD and social support represented appraisal support and belonging support by 78,4 and the rest by other variables outside of research and error.

Based on the results of warpPLS output, it is found that the characteristics of individual members of Persit have a positive influence on the professionalism of the TNI-AD as the National Defence Vanguard which is represented by the long married couple and the decision to marry the soldier with the value of 0.238 beta coefficient which means that every $1 \%$ length of time married and increased decision to marry soldier TNI-AD then soldier professionalism equal to 0,238. Long marriage with a couple who work as soldiers of the Army will increase the professionalism husband as a member. This indicates that the wife's role not only contributes to the child, but also supports the husband's profession in charge of National Defence, especially for PERSIT in Yon Arhanudse as an air defence that has many risks to be taken when the soldier is on duty. The activity becomes something that requires the support of the first is the support of the wife as a member of PERSIT in running its first duty is Helping the Chief of Staff of the Army in the guidance of the wife of soldiers and their families, especially in the mental, physical, welfare and morale so that it can affect the success of the duty of soldiers. Being a wife of a military member requires mental and physical strength because of the activities undertaken as the vanguard of the state land so that social support of the wife is necessary. This is related to the decision to become an Army TNI soldier who served for the defense of the country in the air so that the need for strengthening and training for mentality in running the duty as wife and PERSIT members. The stronger the decision to marry the TNI-AD soldiers the air role, the higher the level of professionalism of the soldiers. Marriage with a sense of mutual attraction with a partner can increase one's desire to stay with his partner. Because one of the builders of the commitment of marriage is a commitment that comes from self-interest is with his partner. The more interested someone with their partner the higher the desire to be together. (Johnson, et al., 1999). The couples faced these challenges by working together to find alternative solutions to the problems at hand. Like the collaborative conflict management model (Galvin in Kharisma, 2013).

The second result is known from the social support consisting of appraisal support and belonging support having a positive influence on PERSIT Yon Arhanudse as a vanguard warrior in air force army, which means that any $1 \%$ 
increase in social support provided by wives as members of the strait can increase professionalism soldiers by $0.718 \%$. This indicates that it is important for soldiers to get good support from families, especially wives, or couples because good support can reduce stress levels of work. The psychological closeness between husband and wife in providing support will increase the hormone oxytocin that can suppress the level of stress felt by the husband as a soldier. Support from wives makes soldiers comfortable and can reduce stress levels of work. Based on the data obtained it supports the results of research that support from the family is a real source for soldiers, because the wife is able to provide peace and comfort for a soldier. So the soldier will be better able to control the level of stress experienced in the work environment. Emotional attention expressed through love, love or empathy, for example when getting problems in the work environment, the expression of attention from the wife is very helpful. (Taylor, et al., 2009: 555).

Powell and Greenhaus (2006) provide a model for understanding how a single role process can enrich another role. In the model, Powell and Greenhaus (2006) suggest that one resource that can be generated in one role that affects the quality of life in another is the resource of social capital. Personal social support gained from families such as wives. Family support is recognized as one of the resources that can enhance the role of work and family, especially in collective culture. Lu et al. (2009) examine the proposition and find that social support is associated.

This is in accordance with Lieberman, (1992) theoretically, social support can decrease the occurrence of events that can lead to anxiety. According to Rush (in Sulistyantini, 1997), stress can be eliminated by enabling social support. A good working atmosphere is created, among others, because of the social support in the environment around the individual, so as to increase morale and prevent stress from the work environment develops into stress.

\section{Conclusions And Recommendations:-}

\section{Conclusions:-}

1. Age above 30 years as much as $67 \%$ while age below 30 years as much as $37 \%$ in 30 years of age. PERSIT who were above 30 years more open-minded related to social support given and already have a good mentality to provide social support. High school education as much as $22 \%$, final education diploma $68 \%$ and scholars as much as $10 \%$. The higher the education pursued by PERSIT then the thinking about social support will be better than the low education. Breadth of thinking for those who married over 10 years who are more skilled in solving problems related to social support and have a better mentality compared with the age of marriage under 10 years. Persit who has a wedding age over 10 years of $65 \%$ and $35 \%$ with age of marriage under 10 years. The number of PERSIT that has the family member less than 5 people as much as $58 \%$ and the rest as much as $42 \%$ with the family member more than 5 people. The more the number of family members turns out to have an impact on social support, especially for those who have children aged 10 years and so still need to get extra attention from a mother, so the social support for the husband is less compared to members of the press. the frequency of duty soldiers out of the island with the same category, but as many as $12 \%$ of soldiers perform tasks abroad one of which to do security of the UN representative more than 3 times in the last 5 years and as many as $88 \%$ of soldiers less than 3 times the departure overseas assignment and even the number of soldiers who perform duty outside the island in the last 5 years as much more than 3 times as much as $92 \%$ and the remaining $8 \%$ to perform tasks out of the island less than 3 times in the period of 5 years because they have to run education in another city. As many as $89 \%$ of the PERSIT is from military families so that husbands must also come from the military, while as many as $11 \%$ of respondents assume that marriage with members of the military can increase self-esteem and in accordance with the desire to have a life partner derived from the military world. Both categories are equally committed to accepting the husband's profession serving as a vanguard of National Defence. As many as 39\% PERSIT works outside the home and as much as $61 \%$ persit PERSIT domestic work.

2. Social support provided is in the form of support through appraisal support and self esteem support. The individual characteristics of PERSIT Chandra Kirana in the Yon Arhanudse 08 neighborhood and social support have a positive influence on the professionalism of the husband as the military's vital role in the leading Guard by $78.4 \%$

\section{Suggestions:-}

It is better to keep the session in Yon Arhanudse 08 held a routine sharing about motivation to share experiences to other peoples whose early marriage age and held a program of routine activities in holding a motivator to foster commitment to give social support to the husband and able to improve a good mentality when the husband must go tasked primarily with knowledge about psychological well-being. 


\section{Bibliography:-}

1. Anderson, J.C., \& D.R., Gerbing. 1988. Structural equation modeling in practice: A Review and recommended two step approach, Psychological bulletin, 103, 411-423.

2. Azman Ismail, Shifa Mohd Nor, Zulkifli Yahya, Ungku Azly Ungku Zahar, Yusof Ismail \& Ainon Jauhariah Abu Samah. 2013. Social Support In Job Performance as An Antecedent of Work Intrusion On Family Conflict: Empirical Evidence. Management, Vol. 18, 2, pp. 37-55.

3. Beehr, T. A., Farmer, S. J., Glazer, S., Gudanowski, D. M. \& Nair, V. N. 2003. The enigma of social support and occupational stress: Source congruence and gender role effets. Journal of Occupational Health Behavior, Vol. 8, p. 220-231.

4. Deeter-Schmelz, D.R. and R. Ramsey. 1997. Considering Sources and Types of Social Support: A Psychometric Evaluation of the House and Wells (1978) Instrument, Journal of Personal Selling \& Sales Management, Vol. 27 (1), p. 49-61.

5. Dolan, Shimon R., Marie R. Van Ameringen, Andre Arsenault. 1992. Personality, Social Support, and Worker's Stress. Relations Industrielles. Vol. 47, No. 1.

6. Fadillah, M. Luthfi. 2010. Pengaruh Stres Kerja terhadap Kepuasan Kerja dengan Dukungan Sosial sebagai Variabel Moderating ( Studi Kasus pada PT. Coca cola Amatil Indonesia, Central Java. UNDIP. Semarang.

7. Fornell \& Larcker. 1981. "Evaluating Structural Equation Modelswith Unobservable Variables and Measurement Error”. Journal of Marketing Research, 18 (February), 39-50.

8. Greenhaus, J. H. dan N. J. Beutell. 1985. Sources of Conflict between Work and Family Roles. Academy of Management Review10(1): 76-88.

9. Gujarati, D. N. 2012. Basic Econometrics. Tata McGraw-Hill Education.

10. Hair, J.E. Jr. R. E., Anderson, R. L. Tatham \& W. C. Black, 1998. Multivariate Data Analysis, Prentice-Hall International. Inc., New Jersey.

11. Hodson, R. 1997. Group relations at work solidarity, conflict and relations with management work and occupation. Journal of applied psychology. 24.

12. Isnovijanti, Tita. Pengaruh Dukungan Sosial terhadap Stres Kerja dan Kepuasan Kerja (Studi Kasus: Di Polres Pati Polda Jateng). Tesis. 2002.

13. Lieke L. ten Brummelhuis \& Tanja van der Lippe. 2010. Effective work-life balance support for various household structures. Vol. 49, Issue 2, p. 173-193.

14. Lu, J. F., O.L. Siu, P. Spector, dan K. Shi. 2009. Antecedents and Outcomes of a Four-Fold Taxonomy of Work-Family Balance in Chinese Employed Parents. Journal of Occupational Health Psychology 14:182-192.

15. Perrewe, Pamela R. \& Daniel C. Ganster. 1989. The Impact of Job Demands and Behavioural Control on Experienced Job Stress. Journal of Organizational Behavior July 10: 213-219.

16. Raeda F. AbuAlRub. 2004. Job Stress, Job Performance, and Social Support Among Hospital Nurses. Journal of Nursing Scholarship, 36:1, 73-78.

17. Veithzal R., Ella Jauvani S. 2009. Manajemen Sumber Daya Manusia untuk Perusahaan: Dari Teori ke Praktik. Jakarta: Rajawali Pers.

18. Yoon, Jeongkoo \& Jun-Cheol Lim. 1999. Organizational Support in The Workplace;The Case of Korean Hospital Employee. Human Relations, Vol. 52, No. 7, P. 923-945. 